\title{
硫化反応を利用しためっき廃液からの選択的金属回収
}

\author{
野村 記生 ${ }^{\mathrm{a}}$, 阿部 裕士 ${ }^{\mathrm{a}}$, 福田 正 ${ }^{\mathrm{a}}$, 柳下 幸一 ${ }^{\mathrm{a}}$ \\ ${ }^{a}$ (侏)三進製作所 $(\bar{T}$ 484-0894＼cjkstart愛知県犬山市羽黒貴船浦 1-2)
}

\section{Selective Separation and Recovery of Metals from Electroplating Wastewater by Sulfidation}

\section{Norio NOMURA ${ }^{\text {a }}$, Hiroshi ABE ${ }^{\text {a }}$, Tadashi FUKUTA ${ }^{\text {a }}$ and Koichi YAGISHITA ${ }^{\text {a }}$}

${ }^{a}$ Sanshin MFG. Co., Ltd.(1-2, Kifuneura, Haguro, Inuyama-shi, Aich 484-0894)

Keywords : Metal Recovery, Metal Sulfide, Plating Wastewater, Selective Sulfidation

\section{1.はじめに}

めっき液はシアン，六価クロムをはじめ，銅，亜鉛，ニッ ケルなど多種の金属および金属塩を使用している。消費量の 数十パーセントは電着して製品に付与されるが, 製品に付着 してめっき槽外に持ち出される量も少なくない。持ち出され た金属塩を含むめっき廃液は, 無害化処理して金属分は水酸 化物の形で混合スラッジとして不溶化する方法が広く利用さ れており，最終的には埋め立て処分されている。混合スラッ ジ発生量は, めっき工程内における金属資源の循環利用など によって減少の方向にあるが, 2002 年における排出量は約 6 万 5 千トン / 年(含水率 : $80 \sim 85 \mathrm{wt} \%$ ) と報告されている ${ }^{1)}$ 。

近年, 廃棄物処分場の枯渇に加え, 環境および省資源の面 から，金属含有廃棄物の再資源化と有効利用が求められてい るものの, 種々の金属が混合されためっき廃水や混合スラッ ジからの再資源化は困難とされている。

多成分系めっき廃液からの金属選択分離法としては, イオ ン交換樹脂法や溶媒抽出法 ${ }^{2)}$ が考えられるが, 研究報告は多 くない。硫化物による金属選択回収は, 溶融飛灰からの重金 属分離回収に関する報告 ${ }^{3)}$ などはあるものの，めっき廃水へ の適用に関する報告例はほとんど見当たらない。

筆者らはこれまでの水酸化物法の欠点を補い, さらに多成 分金属めっき廃水から金属を個別に分離回収することを目的 に, 多硫化ナトリウム $\left(\mathrm{Na}_{2} \mathrm{~S}, \mathrm{Na}_{2} \mathrm{~S}_{2}, \mathrm{Na}_{2} \mathrm{~S}_{4}\right)$, 硫化カルシウ ム $(\mathrm{CaS})$, 硫化水素 $\left(\mathrm{H}_{2} \mathrm{~S}\right)$ などの硫化剂を用いた銅, 亜鉛お よびニッケル混合廃水の硫化反応特性について報告した ${ }^{4) ~ 6) 。 ~}$

従来, $\mathrm{CaS}$ を用いた金属の硫化処理法に関しては Kim ら ${ }^{7)}$, Yahikozawa $5^{8)}$ の各種金属の硫化特性についての報告がある。 $\mathrm{Kim}$ らは $\mathrm{Cd}, \mathrm{Cu}, \mathrm{Pb}, \mathrm{Ag}$ および $\mathrm{Zn}$ の $\mathrm{CaS}$ 水溶液による個 別の硫化実験を行い, 硫化反応処理によっていずれの金属も 水溶液中の残存量は水酸化物処理の場合よりも低減できるこ とを確認している。また, Yahikozawaらは Pb, Cd および $\mathrm{Hg}$ を対象として多硫化カルシウム $\left(\mathrm{CaS}_{\mathrm{x}}\right)$ 溶液による硫化実 験を行い, 各金属溶液の $\mathrm{pH}$ 值に対する硫化反応性について 報告している。
本稿では $\mathrm{CaS}$ による $\mathrm{Cu}, \mathrm{Zn}, \mathrm{Ni}$ の重金属の硫化に対して, $\mathrm{CaS}$ の添加方法, 添加量を変えるとともに, 溶液 $\mathrm{pH}$ 值を反 応期間中一定に保った場合の重金属の硫化反応特性を述べる。 また, 溶液の $\mathrm{pH}$ 調整に基づく各種金属の選択硫化を利用し た重金属の選択回収法の有効性を紹介する。

各種金属を全て硫化物などのスラッジとして分離した場合 には製錬原料としては充分であるが, 高い経済価值を求める には純度の高い金属回収が理想的である。そこで, 分別した 濃厚めっき廃液からの電析回収装置を用いた金属回収事例も あわせて紹介する。

\section{2. 金属の不溶化と物性比較}

めっき廃液から各種金属を不溶化する方法として水酸化物 法, 硫化物法に加えて酸化物として分離する方法がある。水 酸化物法は水酸化ナトリウム, 水酸化カルシウムなどのアル カリと反応させることによって, 水酸化物の難溶性塩を形成 して分離する方法である。

一方, 硫化物法は $\mathrm{Na}_{2} \mathrm{~S}, \mathrm{CaS}$ などと反応させることによって 金属硫化物の難溶解塩を形成して分離する方法である。表 1 に 示すように金属硫化物の溶解度積は水酸化物よりはるかに小 さく，より低濃度まで分離することができる。

一般には金属の難溶性塩を生成した後には沈降分離に加え ろ過分離工程が必要になる。ろ過特性はケークの平均ろ過比 抵抗と圧縮指数で評価する。表 2 に $\mathrm{Cu}, \mathrm{Ni}, \mathrm{Zn}$ の水酸化物, 硫化物および酸化物の平均ろ過比抵抗值を示す。水酸化物は いずれの金属においても比較的難ろ過性であり, Zn は酸化

表 1 金属不溶化物の溶解度積

\begin{tabular}{c|c|c}
\hline 金属イオン & 水酸化物 & 硫化物 \\
\hline $\mathrm{Pb}^{2+}$ & $1.1 \times 10^{-20}$ & $7.0 \times 10^{-29}$ \\
\hline $\mathrm{Cu}^{2+}$ & $1.5 \times 10^{-20}$ & $8.0 \times 10^{-37}$ \\
\hline $\mathrm{Fe}^{2+}$ & $8.0 \times 10^{-16}$ & $4.0 \times 10^{-19}$ \\
\hline $\mathrm{Ni}^{2+}$ & $1.6 \times 10^{-16}$ & $3.0 \times 10^{-19}$ \\
\hline $\mathrm{Cd}^{2+}$ & $2.0 \times 10^{-14}$ & $1.9 \times 10^{-28}$ \\
\hline $\mathrm{Zn}^{2+}$ & $4.0 \times 10^{-16}$ & $8.0 \times 10^{-25}$ \\
\hline $\mathrm{Sn}^{2+}$ & $3.0 \times 10^{-27}$ & $1.0 \times 10^{-27}$ \\
\hline $\mathrm{Fe}^{3+}$ & $3.1 \times 10^{-38}$ & $1.0 \times 10^{-28}$ \\
\hline \multicolumn{2}{|c}{}
\end{tabular}


物が, $\mathrm{Cu}$ は硫化物が, $\mathrm{Ni}$ については酸化物, 硫化物のろ過 性が優れていた。

酸化物法は沈降速度, ろ過性, 含水率の観点から優れた物 性を示すが, 実用的には一旦水酸化物にしてから脱水反応な どを行い酸化物にする必要があることからも経済性, 操作性 の点で問題が残る。

従来利用されている水酸化物法は安価な薬品で処理できる 方法であるが, 近年のめっき薬品の変化もあって要求される 排水規制值への対応, 沈殿物の安定性, 処理の確実性などに 注意する必要がある。一方, 硫化物法は操作性, 安全性の面 に不安があるものの, 多成分系金属溶液から分離回収が可能 で，資源回収と廃水処理を兼ねた有望な処理法として期待で きる。

\section{3. 不均一硫化反応による多成分系金属溶液の硫化順位}

多成分系金属溶液からの各金属の個別分離の可能性につい て, $\mathrm{Cu}, \mathrm{Ni}, \mathrm{Zn}$ などを含む混合溶液について定性的に検討し た。硫化剤として $\mathrm{Na}_{2} \mathrm{~S}$ を用いた反応を化学平衡計算によっ て検討した。図 1 に平衡計算結果を示す。平衡計算は熱力学 平衡計算ソフト (HSC Chemistry, Outokumpu Research Oy Information Service) を用いた。金属濃度は水 $5.5 \times 10^{-2} \mathrm{kmol}$ に各金属塩(硫酸塩) $2.0 \sim 3.0 \times 10^{-6} \mathrm{kmol}$ を加え, 数百 $\mathrm{dm}^{3}$ になるよう設定した。また, 温度 : $25^{\circ} \mathrm{C}$, 圧力 : 常圧として,

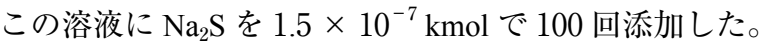

また，反応時の溶液 $\mathrm{pH}$ 值が硫化反応に影響することは, これまでの実験で明らかであるが，本計算では酸あるいはア ルカリの添加による $\mathrm{pH}$ 調整は省いた。

図 1 から金属硫化物の生成順位は $\mathrm{Cu}^{2+}$ が最も早く, $\mathrm{Cu}_{2} \mathrm{~S}$ および $\mathrm{CuS}$ を生成することがわかる。また, $\mathrm{Cu}^{2+}$ の反応期

表 2 金属不溶化物の平均万過比抵抗值

\begin{tabular}{c|c|c|c}
\multicolumn{3}{c}{} & \multicolumn{3}{c}{$\alpha \mathrm{m}=\times 10^{12} / \mathrm{m} \cdot \mathrm{kg}^{-1}$} \\
\hline & 銅 & ニッケル & 带鉛 \\
\hline 水酸化物 & 8.6 & 9.5 & 7.5 \\
\hline 酸化物 & 4.5 & 4.6 & 5.1 \\
\hline 硫化物 & 3.4 & 5.7 & 7.1 \\
\hline \multicolumn{3}{|c}{ ろ過圧 : $9.31 \times 10^{4} \mathrm{~Pa}$ における值 }
\end{tabular}

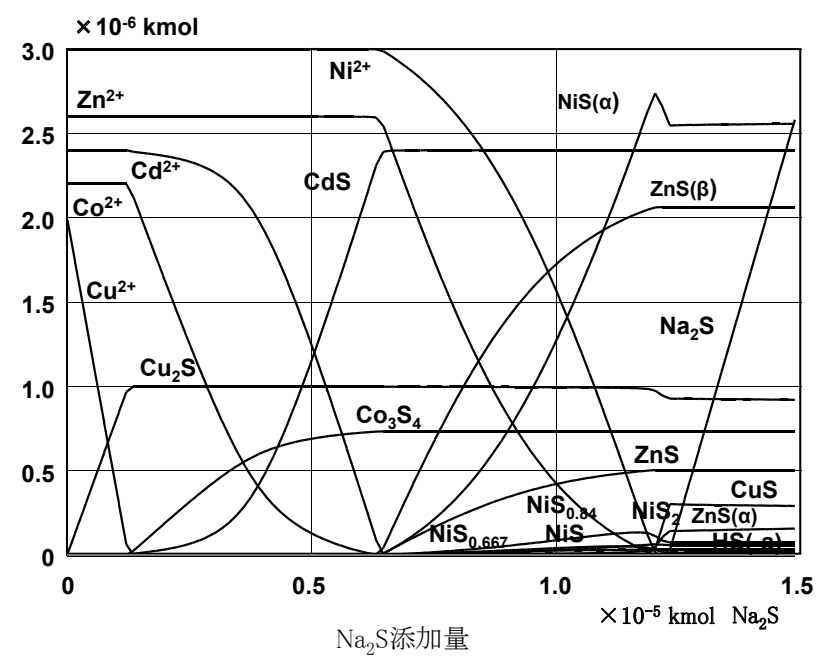

図 1 化学平衡計算による多成分系金属溶液の不均一硫化反応
間中他の金属イオンは反応に関与せず，当初の状態を保持し ていることも予見できる。 $\mathrm{Cu}^{2+}$ の反応が完了した後は, $\mathrm{Co}^{2+}$ が優先的に反応し, 以下, $\mathrm{Cd}^{2+}, \mathrm{Zn}^{2+}, \mathrm{Ni}^{2+}$ が金属種に優先 性はあるものの，同時に反応することが伺える。

本図より, $\mathrm{Cu}_{2} \mathrm{~S}(\mathrm{CuS}), \mathrm{Co}_{3} \mathrm{~S}_{4}, \mathrm{CdS}$ の個別回収における選 択率は $95 \%$ 以上期待することができる。また, 上記 3 種の 金属を分離した後の $\mathrm{ZnS}, \mathrm{NiS}$ の選択分離については, $\mathrm{pH}$ 調整が必要であることが推測される。

\section{4. 硫化カルシウムによる銅, 亜鉛, ニッケルの選択 硫化反応}

\section{4. $1 \mathrm{Cu}, \mathrm{Zn}, \mathrm{Ni}$ 単一溶液の硫化反応特性}

4. 1. $1 \mathrm{Cu}, \mathrm{Zn}, \mathrm{Ni}$ 単一溶液の硫化

図 2 に, $\mathrm{CaS}$ 粉末と各種金属溶液の硫化反応によって得ら れたろ液の金属イオン濃度および $\mathrm{pH}$ と $\mathrm{CaS}$ 添加量との関係 を示す。本図より, $\mathrm{Cu}$ 水溶液に $\mathrm{CaS}$ 粉末 1 当量を添加して も $C / C_{0}$ は約 0.5 までしか減少せず, 溶液中の全 $\mathrm{Cu}$ を硫化沈 殿させるためには $\mathrm{Zn}, \mathrm{Ni}$ の場合に比べて約 2 当量を要した。 このような $\mathrm{Cu}$ 溶液の $\mathrm{CaS}$ による硫化特性は $\mathrm{Na}_{2} \mathrm{~S}$ では認め られていないことから, $\mathrm{CaS}$ の $\mathrm{Cu}$ 溶液中での解離度が $\mathrm{Ni}$, $\mathrm{Zn}$ 溶液中での解離度より低いことが原因であり, 生成スラ リーのXRD 測定結果によっても確認された。

図 2 より, $\mathrm{CaS}$ 粉末を用いた $\mathrm{Cu}$ の硫化ではかなりの量の 固体 $\mathrm{CaS}$ が残存することから, $\mathrm{CaS}$ 粉末をあらかじめ水に 溶解させた後, $\mathrm{Cu}$ 溶液に加えたときの液一液反応系におけ る $\mathrm{Cu}$ の硫化反応を行った。その結果, 液一液反応系では $\mathrm{Cu}$ は $\mathrm{Zn}, \mathrm{Ni}$ とほぼ同じく $\mathrm{CaS}$ 約 1 当量でろ液中の濃度は $1 \mathrm{mg} / \mathrm{dm}^{3}$ になった。このとき生成した沈殿物の XRD 結果よ り, $\mathrm{CuS}$ のピークのみが存在し, 未反応の $\mathrm{CaS}$ は確認され なかった。

一方, $\mathrm{Zn}, \mathrm{Ni}$ 溶液ではともに $\mathrm{CaS}$ を 1.1 当量 $(\mathrm{mol}-\mathrm{Ca} / \mathrm{mol}-$ $\mathrm{Me})$ 以上添加したときに金属イオン濃度を $1 \mathrm{mg} / \mathrm{dm}^{3}$ まで低 減することができた。また, $\mathrm{CaS}$ を約 1 当量分添加するまで は溶液中の $\mathrm{pH}$ は $\mathrm{Zn}$ では $\mathrm{pH}=4.5 \sim 5.5, \mathrm{Ni}$ では $\mathrm{pH}=6.0$ 〜 7.0 のほぼ一定值を保持した。

比較のために $\mathrm{Cu}, \mathrm{Zn}, \mathrm{Ni}$ 溶液に $\mathrm{Na}_{2} \mathrm{~S}$ 溶液 $\left(6.8 \times 10^{-4} \mathrm{~mol} / \mathrm{dm}^{3}\right)$ を加えたときの金属濃度変化および $\mathrm{pH}$ 変化と, $\mathrm{Na}_{2} \mathrm{~S}$ 添加量 の関係を確認した結果, $\mathrm{Zn}$ と $\mathrm{Ni}$ は $\mathrm{CaS}$ の場合と同様, $\mathrm{Na}_{2} \mathrm{~S}$ の添加量の増大とともにろ液中の濃度はほぼ直線的に減少し,

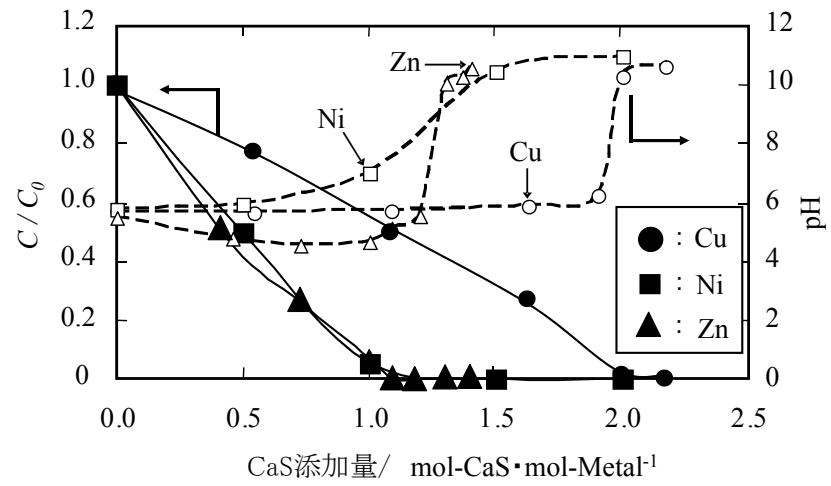

図 $2 \mathrm{CaS}$ の添加にともなうろ液の金属濃度および $\mathrm{pH}$ 変化 
$\mathrm{Na}_{2} \mathrm{~S}$ を 1.5 当量添加した時点でのろ液中の残存 $\mathrm{Zn}$ 濃度は $1 \mathrm{mg} / \mathrm{dm}^{3}$ 以下, $\mathrm{Ni}$ 濃度は $5 \mathrm{mg} / \mathrm{dm}^{3}$ まで低減することが認め られた。

4. 1. $2 \mathrm{Cu}, \mathrm{Zn}, \mathrm{Ni}$ の硫化に及ぼす $\mathrm{pH}$ の影響

図 3 に金属溶液 $\mathrm{pH}$ 值を一定に保ちつつ $\mathrm{CaS}$ を添加したと きのろ液中の $\mathrm{Cu}, \mathrm{Zn}, \mathrm{Ni}$ 濃度と $\mathrm{pH}$ との関係を示す。溶液 は $\mathrm{H}_{2} \mathrm{SO}_{4}$ および $\mathrm{NaOH}$ を用いて所定の $\mathrm{pH}$ 值に調整した後, $\mathrm{CaS}$ 粉末 1 当量を 10 回に分けて添加し, 万液の金属濃度を 測定した。 $\mathrm{CaS}$ の添加にともなう $\mathrm{pH}$ 変化は $\mathrm{H}_{2} \mathrm{SO}_{4}$ を加える ことによって調整した。 $\mathrm{Cu}$ の硫化では, $\mathrm{pH}$ 值の中性化にと もなって $C / C_{0}$ は悪くなり $\mathrm{Cu}$ がろ液中に残存する。一方, 強 酸性域 $\left(\mathrm{pH} 1\right.$ ～2) では同量の添加で $C / C_{0}$ を $0.13 \sim 0.15$ まで 低減することができ, さらに 1.5 当量の $\mathrm{CaS}$ 添加では液中の $\mathrm{Cu}$ はほぼ完全に除去することができた。

$\mathrm{Zn}$ の場合は $\mathrm{pH}=2.0 \sim 4.0$ において $\mathrm{pH}$ の上昇とともに ろ液中の $\mathrm{Zn}$ 濃度は減少し, $\mathrm{pH}=4$ では $\mathrm{Zn}$ の $C / C_{0}$ は 0.01 以下となった。 $\mathrm{Ni}$ の硫化では, $\mathrm{pH}=2.0$ 〜 5.5 までは $80 \%$ 以上の $\mathrm{Ni}$ が液中に残存したが, $\mathrm{pH}$ 值を 5.5 以上に上げると $\mathrm{Ni}$ 濃度はほぼ直線的に減少し, $\mathrm{pH}=7.5$ では $\mathrm{Ni}$ の $C / C_{0}$ は 0.1 以下となった。

4. 2 模擬めっき廃水中 $\mathrm{Cu}, \mathrm{Zn}, \mathrm{Ni}$ の選択硫化

4. 2. 1 化学平衡計算による選択硫化予測

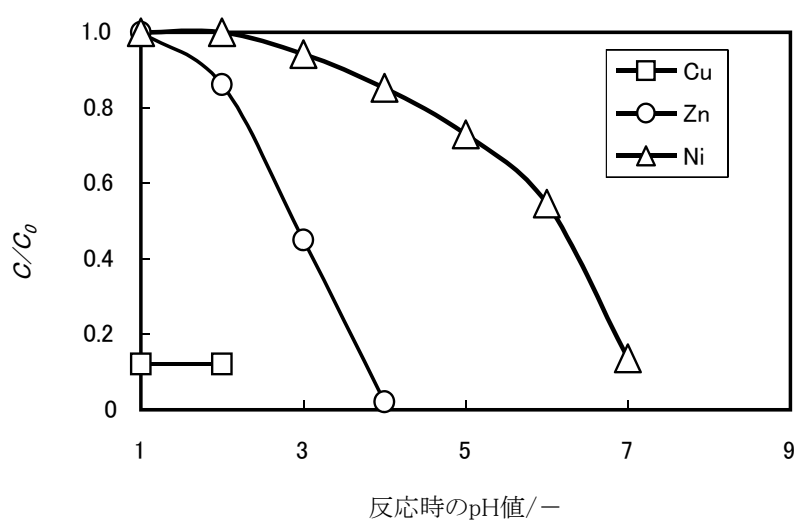

図 3 金属の硫化に及ぼす $\mathrm{pH}$ の影響

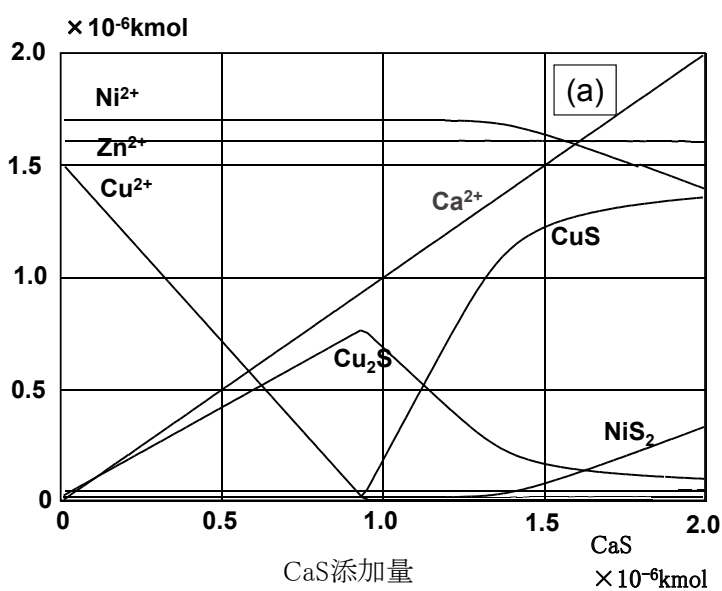

前項と同じ化学平衡計算によって反応状況を予測してみた。 その結果を図 4 (a) および (b)に示す。計算は, 実験条件に合 わせて初期の各金属イオン濃度を約 $100 \mathrm{mg} / \mathrm{dm}^{3}$ に設定する ため, $\mathrm{Cu}=1.50 \times 10^{-6} \mathrm{kmol}, \mathrm{Zn}=1.60 \times 10^{-6} \mathrm{kmol}, \mathrm{Ni}=$ $1.70 \times 10^{-6} \mathrm{kmol}, \mathrm{H}_{2} \mathrm{O}=5.5 \times 10^{-2} \mathrm{kmol}$ とした。主な反応 生成物は $\mathrm{CuS}, \mathrm{Cu}_{2} \mathrm{~S}, \mathrm{ZnS}, \mathrm{NiS}, \mathrm{NiS}_{2}$ および $\mathrm{S}$ と仮定して計算 した。なお，生成物は以上の他に $\mathrm{HSO}_{4}{ }^{-}, \mathrm{H}^{+}$なども生成す るが図では表示を省略した。

第 1 段反応 $(\mathrm{a}$ 図 $)$ では硫酸添加によって初期 $\mathrm{pH}$ を 2.0 と した後, $2.0 \times 10^{-8} \mathrm{kmol}-\mathrm{CaS}$ を 100 回加えた。CaS の添加に よって $\mathrm{Cu}^{2+}$ は一旦 $\mathrm{Cu}_{2} \mathrm{~S}$ を生成するが, $\mathrm{Cu}^{2+}$ が全て $\mathrm{Cu}_{2} \mathrm{~S}$ に 硫化された後, $\mathrm{Cu}_{2} \mathrm{~S}$ は減少し始め $\mathrm{CuS}$ に変化する。 $\mathrm{CaS}$ 添 加量が $1.4 \times 10^{-6} \mathrm{kmol}$ までは $\mathrm{Zn}^{2+}, \mathrm{Ni}^{2+}$ は未反応のままで あることが期待される。

また，硫化銅を分離した後のろ液を用いて第 2 段反応 $(\mathrm{b}$ 図）を, 初期 $\mathrm{pH}: 4.0$ として計算した。CaSの添加にともな い $\mathrm{ZnS}, \mathrm{NiS}$ がほぼ同時に沈殿し始め, $\mathrm{ZnS}(\beta$ 型 $), \mathrm{ZnS}$ お よび微量の $\mathrm{ZnS}(\alpha$ 型 $)$ の結晶構造の異なった 3 種類の亜鉛硫 化物と, $\mathrm{NiS}(\alpha$ 型 $), \mathrm{NiS}_{2}$ および微量の $\mathrm{NiS}$ が生成される。 本計算結果より, $\mathrm{ZnS}$ の選択率が $65 \%$ 以上は可能であるこ とが示唆された。

4. 2.2 分別ケークの金属選択率

$\mathrm{Cu}^{2+}, \mathrm{Zn}^{2+}, \mathrm{Ni}^{2+}$ 初濃度 : 約 $100 \mathrm{mg} / \mathrm{dm}^{3}$ の混合溶液を試 液として, CaS による金属選択率 [(特定金属重量/全金属 重量) $\times 100]$ を調べた。溶液の $\mathrm{pH}$ を一定に保ちつつ, 一定 量の $\mathrm{CaS}$ 粉末を数回に分けて添加した。その後, 試料溶液 はマグネティックスターラーによって 10 分間撹拌した後,

10 分間静置した。このとき硫化反応によって生成したスラ リーを，孔径 $0.45 \mu \mathrm{m}$ のメンブレンフィルターでろ過し， ろ 液の金属イオン濃度を ICPによって測定した。

$\mathrm{Cu}^{2+}$ は $\mathrm{pH}=1.8 \sim 2.0, \mathrm{Zn}^{2+}$ は $\mathrm{pH}>4.0, \mathrm{Ni}^{2+}$ は $\mathrm{pH}>7.5$ の条件下でそれぞれ同当量の $\mathrm{CaS}$ を添加することによって, これらの金属はほぼ完全に金属硫化物として沈殿分離するこ とが認められた。

第 1 段で $\mathrm{pH}=1.8$ ～ 2.0 に固定した混合金属溶液に対し

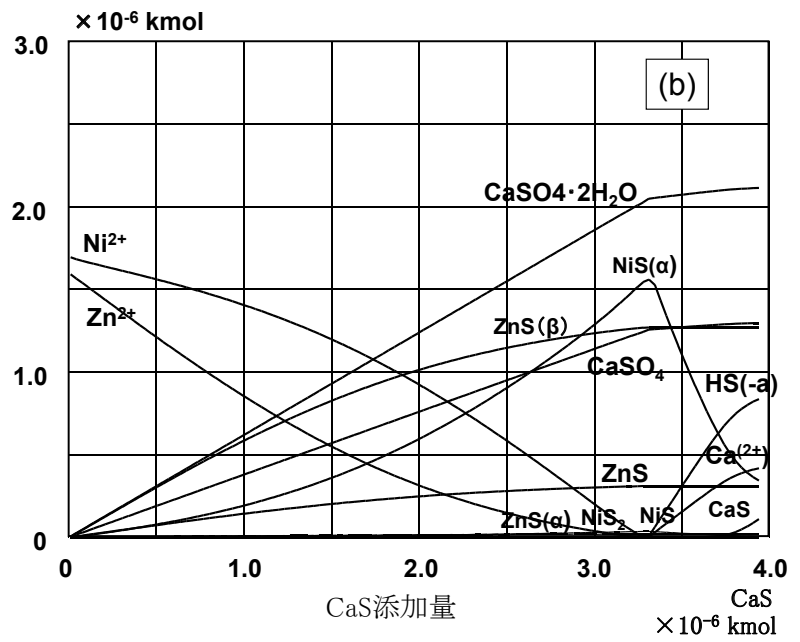

図 4 (a) 化学平衡計算による $\mathrm{Cu}, \mathrm{Zn}, \mathrm{Ni}$ 混合溶液からの $\mathrm{Cu}$ の選択硫化傾向 (b) 化学平衡計算による $\mathrm{Zn}, \mathrm{Ni}$ 混合溶液からの $\mathrm{Zn}$ の選択硫化傾向 
て $\mathrm{Cu}^{2+}$ の 1.2 倍当量の $\mathrm{CaS}$ 粉末の添加による硫化処理を行 い, 続いて第 2 段では第 1 段処理後のろ液を $\mathrm{pH}=5.5 \sim 6.0$ に固定しながら, $\mathrm{Zn}^{2+}$ の 1.5 倍当量の $\mathrm{CaS}$ 粉末を添加して第 1 段と同様の処理を行った。第 $1 ， 2$ 段処理で生成した沈殿 ケークを王水で溶解して，ケーク中に含まれる $\mathrm{Cu}, \mathrm{Zn}, \mathrm{Ni}$ および $\mathrm{Ca}$ の組成を測定し各金属の選択率を求めた。

図 5 に，第 $1 ， 2$ 段操作より生成したケーク中に含まれる 各金属の選択率を示す。本図より，第 1 段操作ではケーク中 にごく微量の $\mathrm{NiS}$, カルシウム化合物を含むものの, $\mathrm{Cu}$ の 選択回収率は $99.5 \%$ となり，良好な選択回収性が得られた。 次に，第 2 段操作における $\mathrm{ZnS}$ の分別沈殿では, NiS の共沈 の影響によって ZnS の選択率は $81.4 \%$ となった。

本実験より，3成分系金属廃液の $\mathrm{pH}$ 調整による選択硫化 処理において, $\mathrm{CuS}$ は他の金属硫化物と沈殿生成 $\mathrm{pH}$ 域が離 れているため, 比較的容易に高選択率で分離回収することが 可能であった。また，ZnSでは $80 \%$ 程度の選択率に留まっ たが,これまでの処理条件と比べ $\mathrm{pH}$ 条件を中性側に設定し たこと, $\mathrm{ZnS}$ と $\mathrm{NiS}$ の沈殿生成 $\mathrm{pH}$ が近いため, $\mathrm{pH}$ の微小 の変化によっても NiS の共沈量が増大する可能性があると 推測される。

\section{5．再資源材としての付加価値向上策検討}

前節では多成分金属を含むめっき廃液から選択的に金属を 分離回収する方法を紹介した。ここで得られる硫化物中の金 属の含有率は $20 \sim 30 \%$ 程度と予測される。

めっき工程の水洗水を対象にボンベ型イオン交換塔を工程 別に設置し，水洗水の循環を行い，飽和したイオン交換塔は 引き取り再生専用工場で金属ごとの分別再生が行われている ${ }^{9)}$ 。 イオン交換塔より排出される再生溶離液中のニッケル，銅は それぞれスラッジ化し，山元還元される。しかしながら，こ のシステムでは経済的な回収メリットが小さく, さらなる改 善を必要とする。

そこで, 付加価值を高めるためにイオン交換樹脂の再生溶 離液, めっき濃厚廃液を対象に特殊ロール型電析装置を開発 した。図 6 に示したロール型電析装置の電流効率は, 対象液 の種類, 濃度, 不純物によって異なるものの, $\mathrm{Ni} て ゙ 40 〜$

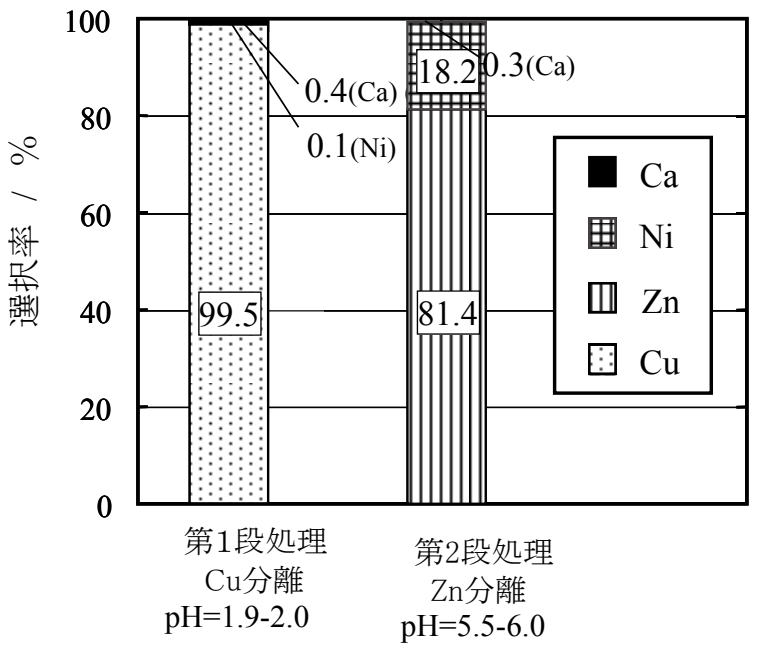

図 5 Zn， Ni 混合溶液からの CaS による選択分離
$90 \%, \mathrm{Cu}$ で 70 〜 95\%程度である。図 7 に本装置を用いて 回収した $\mathrm{Cu}$ および $\mathrm{Ni}$ 金属片を示す ${ }^{10)}$ 。回収金属は $98 \%$ 以 上の純度のものが得られており，高い付加価值を有する。

$\mathrm{Ni}$ 電析では電解液の純度が析出電流効率に大きく影響す るため銅, 鉄, 亜鉛, スズ, クロムなどの混入を極力避ける 必要がある。この場合には先に述べた選択硫化を利用した不 純物除去を組み合わせたプロセスも実用的である。

また, めっきプロセスから排出される回収液, 比較的濃度 の高い水洗水を濃縮(蒸発濃縮, RO 濃縮など)することによ り, 不純物の混入が少なく電解液の金属濃度を上げることに より安定した高い電流効率を得ることができる。

\section{6.おわりに}

本稿では従来混合スラッジとして廃棄処分されている多成 分系めっき廃液に対して硫化反応を利用することで金属の選 択分離回収が可能なことを述べた。使用する $\mathrm{CaS}$ は廃石膏 ボード $\left(\mathrm{CaSO}_{4}\right)$ の還元熱分解によって効率的に生成すること が確認されていることから ${ }^{11)}$ ，最終的には廃石膏ボードの 有効利用による金属含有廃液からの金属資源回収への応用を 目指している。 $\mathrm{Cu} ， \mathrm{Zn}, \mathrm{Ni}$ などは自然界における金属鉱石 の多くが硫化物で存在しており，製鍊プロセスも硫化鉱石を 基本としているため，再資源化も容易と考えられる。さらに， 製錬工程で副生される硫黄酸化物も硫酸などの原材料として 循環利用されており，本研究による金属循環システムはこれ らのプロセスとも融合できる。

しかしこの金属循環システムはスラッジ形状での売却にな

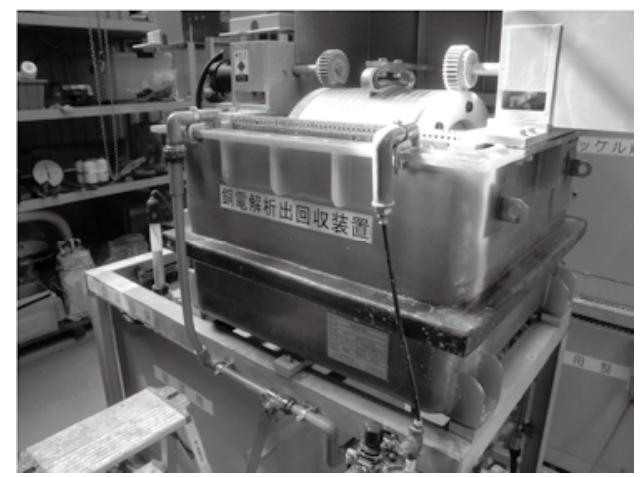

図 6 ロール型電析装置
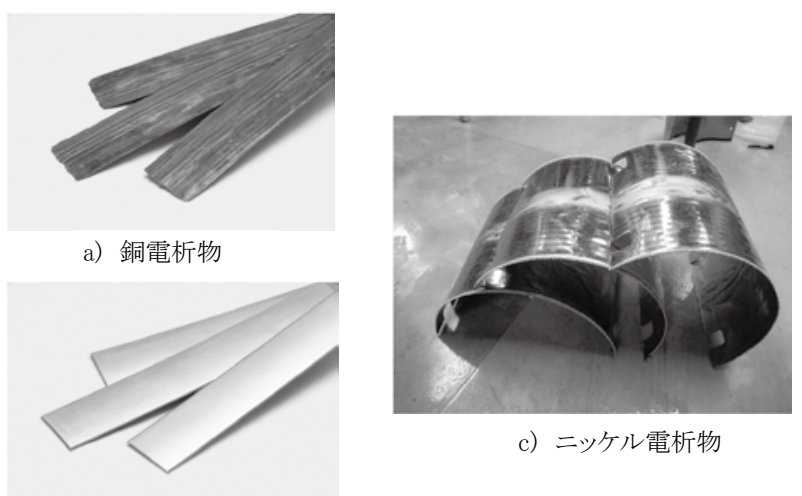

c）二ッケル電析物

b）二ッケル電析物

図 7 電析金属回収物 
るため，金属含有率に限度があり，輸送コストなどを考慮す るなどさらに改善が求められる。

そこで濃厚液から直接金属を回収する電析装置の適用事例 を紹介した。この電解回収を効果的に行うためには,できる 限り不純物を含まないような系統別の分別が重要になってく る。

めっき廃液の処理は，排水規制にあわせて無毒化するため の廃水処理装置から, 経済的な処理方法を目指して水資源, 金属資源の有効利用を含めた処理システムに変化してきた。 今後さらに環境への配慮と資源有効利用・再資源化の重要性 が高まっている。

今後の環境保全には工程内の精製，長寿命化，薬品利用効 率を高め環境負荷の低減が不可欠である。また，工程内で不 純物除去と再利用を行い, 廃棄する場合は分別と濃縮を徹底 する。さらに，資源エネルギーの回収を行い，最終的には無 害化処理と適正な処分を行う。このためには廃水処理だけで なく, 工程内管理を含めた全体的なシステム設計が重要に なってくる。

本稿が地球環境にやさしく, めっき産業の省資源, 省エネ ルギーの参考の一助として活用していただければ幸いである。

\section{謝辞}

ここに紹介した内容の一部は, 愛知県循環型社会形成推進
事業補助事業費補助金の支援を受けて行われました。ここに 感謝申し上げます。

(Received August 8, 2011)

\section{文献}

1 ）全国鍍金工業組合連合会編；平成15年度製造産業技術対策調査 「めっきスラッジのリサイクルに関する実態調査」,p.12 (2004).

2 ）河原正泰,豊福秀徳; J.MMIJ, 123, 45 (2007).

3 ）木成寿秀, 水上俊一, 河端博昭, 片山 学, 龟岡義文; 日本機械学 会第6回環境工学総合シンポジウム講演用要旨集, p.198 (1996).

4 ）福田 正, 松田仁樹, 小島義弘, 瀬戸冨士雄, 柳下幸一; 表面技術, 56, 607 (2005).

5 ）福田 正, 松田仁樹, 小島義弘, 瀬戸冨士雄, 柳下幸一; 表面技術, 57, 77 (2006)

6 ）近藤秀幸, 藤田隆文, D. Kuchar, 福田 正, 松田仁樹, 柳下幸一; 表 面技術, 57, 901 (2006).

7 ) B. M. Kim ; AIChE Symposium Series, 77, 39 (1980).

8 ) K. Yahikozawa, T. Aratani, R. Ito, T. Sudo, T. Yano ; Bull. Chem. Soc. Jpn., 51, (2), 613 (1978).

9 ）福田 正; 表面技術, 45, 860 (1994).

10）愛知県産業労働部地域産業課；リサイクル社会の構築に向けて, p.36 (愛知県, 2011年2月).

11) N. Mihara, T. Fukuta, H. Matsuda ; Proc. of the 71st Annual Meeting of the Society of Chem. Eng. Jpn, p.143 (2006) (in Japanese). 